V závere svojej monografie Lubomír Chalupka konštatuje, že bude pre neho ako autora dostatočným zadostučinením, ak sa predložený titul spolu s jeho prechádzajúcim dielom stane impulzom pre rad sprievodných otázok a zamyslení, resp. rozhodnutí pre prehĺbenie záujmu o prezentovanú oblast’ najmä $\mathrm{z}$ radu príslušníkov mladšej generácie. Je nepochybné, že každý, kto v budúcnosti prejaví záujem o slovenskú hudbu a jej štúdium, nebude môct' Chalupkove tituly obíst'. V prípade tejto monografie (podobne ako aj predošlých prác) o fundovanosti autora a jeho hlbokej znalosti, ktorá je výsledkom jeho celoživotného záujmu o danú problematiku, svedčí samotný rozsah práce a jej komplexný a tiež objektívny obsah. Toho dôkazom je skutočnost', že v rámci textu sú zahrnuté i mená a tvorba skladatelov, ktorí boli z rozličných dôvodov $\mathrm{v}$ doterajšej muzikologickej spisbe opomínaní, resp. ich mená sa v odbornej literatúre vyskytujú vôbec po prvýkrát. Na 879 stranách sa v ucelenej koncepcii prezentuje vývoj slovenskej hudby a hudobnej kultúry 2. polovice 20. storočia, ošetrený poznámkovým aparátom tvoreným 1401 odkazmi na príslušnú literatúru a pramene, spolu so 68 analyzovanými dielami od 36 autorov, ktoré dokumentuje 307 notových príkladov. Analytické texty predkladajú pred čitatela osobitú výzvu, ide však o autorov osobitý štýl písania, ktorý vo výsledku poskytuje hlboký prienik do hudobného diela vo všetkých jeho štrukturálnych a formových aspektoch, doplnený informáciami o jeho genéze, verejnom uvedení, resp. zázname na zvukovom nosiči a o celkovej recepcii. Je obdivuhodné a určite nie bežné, že titul takýchto kvalít je výsledkom jedinca, a nie celého tímu. Jeho prínos je sledovatelný vo viacerých oblastiach od vedeckého cez pedagogické zameranie, predstavuje však aj mimoriadnu motiváciu a inšpiráciu pre rad dalších bádatelov, tak ako by si to pri všetkej skromnosti želal sám autor.

Michal Ščepán

\title{
Slávka Kopčáková: Aktuálne otázky hudobnej estetiky 20. a 21. storočia
}

Edícia Opera Philosophica. Prešov : Filozofická fakulta Prešovskej univerzity v Prešove, 2020, 225 s. ISBN 978-80-555-2522-8

Na pôde Inštitútu estetiky a umeleckej kultúry FF PU v Prešove vyšla $\mathrm{v}$ uplynulom roku monografia venovaná aktuálnym otázkam novodobej hudobnej estetiky. Prešovský Inštitút v posledných rokoch strategicky investuje väčšinu svojej vedeckej kapacity do interdisciplinárneho výskumu. Na pravidelných stretnutiach Súradnice estetiky, umenia a kultúry udržuje tento interdisciplinárny duch nielen $\mathrm{v}$ domácom estetickom myslení, ale snaží sa ho etablovat aj v medzinárodnom kontexte. Takže nie je náhoda, že v prešovskom bádatel'skom hladáčiku je hudobné estetično rovnocenné estetičnu vizuálnemu, literárnemu či multimediálnemu. Pre hudobnú estetiku na Slovensku je to dobrá správa.

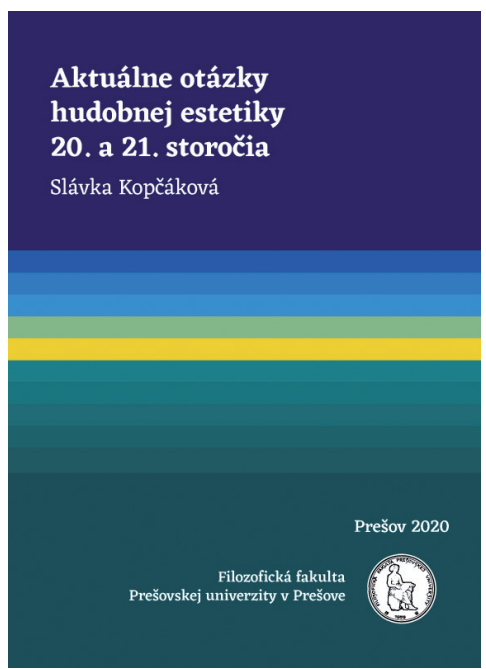


Slávka Kopčáková, autorka monografie Aktuálne otázky hudobnej estetiky 20.a 21. storočia, má vo svojom akademickom portfóliu viacero monografických príspevkov $\mathrm{k}$ dejinám slovenskej hudobnej kultúry. Pred pár rokmi pripravila knižný profil nestora slovenskej hudby Ladislava Burlasa, aktualizáciu svojho staršieho textu, do hĺbky prepracovanú a doplnenú o výsledky pokračujúceho pätnástročného výskumu (Ladislav Burlas, Prešov, 2002; Ladislav Burlas a slovenská hudobná kultúra, Prešov, 2017). Najnovšia práca Slávky Kopćákovej patrí do odlišného výskumného balíka, ktorý je u autorky zastúpený titulom Vývoj hudobno-estetického myslenia na Slovensku $v$ 20. storočí (Prešov, 2013). Jej najnovšiu publikáciu možno považovat’ za nadväzovanie na túto líniu hudobnoestetického výskumu. Tentoraz ide o prehladné výklady štyroch univerzálnych hudobnoestetických pojmov, okolo ktorých sa historicky vytvoril svojbytný diskurz a ktoré zostávajú trvalou témou aj novodobého myslenia o hudbe. Každému pojmu je venovaná samostatná kapitola s výkladom podstaty konkrétneho diskurzu, t. j. kedy, v akej súvislosti a tiež kto sa podielal na etablovaní jeho základných téz. Autorka pritom nezabúda ani na relevantné príspevky aktuálnej slovenskej hudobnej estetiky, ktoré uvádza do kontextu a príslušnej línie medzinárodného estetického myslenia.

Slávka Kopčáková sa podujala zosumarizovat novodobé prístupy $\mathrm{k}$ redefinovaniu štyroch základných kategórií hudobnej estetiky. Prvá kapitola sa zaoberá pojmom hudobná estetika, druhá kapitola predkladá rôzne postoje $\mathrm{k}$ definovaniu hudobného myslenia, tretia sa sústreduje na podstatu pojmu hudobné dielo a posledná, štvrtá kapitola otvára na Slovensku dosial prehliadanú problematiku hudobnej ontológie. Všetky uvedené pojmy-kategórie sú $\mathrm{v}$ úzkom vztahu k základným hudobnofilozofickým otázkam, na ktoré sa nabalujú rôzne alternatívne diskurzy reflektujúce (každý inak) súčasnú špecifickú kultúrnu situáciu. Netýkajú sa len typicky novodobého komplexného chápania nedelitelnej ontologickej a noetic- kej podstaty hudobného umenia. Alternatívne filozofické diskurzy sledujú najmä líniu dištinkcií medzi estetikou a umenovedou, t. j. dištinkcií medzi estetikou hudby v umenovednom zmysle (zastúpenou tradičnou muzikológiou) a estetikou hudby prikláňajúcou sa skôr k etnomuzikologickej stratégii uvažovania o hudbe. Je len samozrejmé, že tieto zásadne odlišné prístupy chápu odlišne aj kompetencie estetiky. Estetika, ktorá chápe hudbu v objektovom zmysle, sa aj vo svojich aplikáciách radikálne líši od hudobnej estetiky, ktorá pracuje aj s činnostným konceptom hudby. Táto línia síce nie je v centre záujmu autorky, ale logicky sa kde-tu vynorí, aspoň ako „vedlajší produkt“ sumarizácie rôznych stanovísk. Napokon, autorka už na začiatku deklaruje vlastné stanovisko a toho sa v jednotlivých výkladoch dôsledne drží: vybrané kategórie chápe ako svojbytné oblasti estetiky, ktoré „vymedzujú konštitutívne vlastnosti disciplíny, jej aktuálne pozície vo sfére umenovedného a filozofického nazerania na hudbu“.

$\mathrm{V}$ úvode publikácie autorka odmieta tradičný historizujúci prístup $\mathrm{k}$ jednotlivým témam $\mathrm{v}$ podobe rekapitulácie ich doterajšieho vývoja. Každá kapitola však nevyhnutne (!) sleduje líniu od historicky etablovaného klasického chápania pojmov $\mathrm{k}$ zostručnenému sumáru novodobých prístupov, ktoré ich významy aktualizujú. Autorka sa nevyhýba ani výzvam a kontroverziám. Tematizuje napríklad rozdiel medzi pojmami „hudobná estetika“ a „estetika hudby“. Otázku adjektivizácie pojmov iste možno z dobrých dôvodov považovat’ za marginálnu. Nemusí však zostat’ výzvou len pre formálnu argumentáciu, ale i pre autentické heuristické myslenie. Je zrejmé, že autorka si bola plne vedomá úskalí výkladu viacerých aspektov estetických kategórií, ktorým sa rozhodla venovat', pretože hned' v Úvode jasne deklarovala neochotu „predstierat istotu“ vlastného poznania a na viacerých miestach sa priznáva $\mathrm{k}$ rezignácii na osobný názor. Pripúšta, že $\mathrm{v}$ mnohých problematických otázkach možno prijat’ pragmatický postoj a považovat' ich len za otázky jazykového úzu. 
$S$ ohladom na dramaturgiu textu monografie sa ponúkajú dve možnosti jej čítania. Radenie kapitol môže pôsobit aditívne, nekonfliktne ako autorkin osobný reader's digest súčasnej hudobnej filozofie. Pred skúseným čitatelom sa však môže odvíjat aj „inýc text. Tvorivé čítanie napríklad odhaluje v následnosti kapitol vnútorný klimax, od východiskovej kategórie „hudobná estetika“ cez „hudobné myslenie“ a "hudobné dielo“ až po „hudobnú ontológiu“ ako strešnú kategóriu a spoločnú nadstavbu všetkých ostatných. Nie je však celkom jasné, či túto stratégiu sledovala aj autorka monografie, alebo či je pocit dynamizmu textu len výsledkom implikovaného a motivovaného čítania, či dokonca nadinterpretácie.

Publikácia Slávky Kopčákovej nesleduje len vedecké, ale i pragmatické ciele. Poskytuje seriózny a poctivo pripravený materiál pre univerzitné hudobné vzdelávanie. $\mathrm{Hu}$ dobná estetika u nás sa v oblasti edukácie pevne drží neproblémových historických téz. Dokonca aj akademická hudobná estetika málokedy otvára diskusie týkajúce sa reálnej situácie hudby $\mathrm{v}$ aktuálnej hudobnej kultúre. Na našich univerzitách sa nezvykne diskutovat’ o povahe hudobného estetična (napríklad aký je vztah zvukového a hudobného estetična), napriek tomu, že súčasná hudobná tvorba (naprieč žánrami) už dávno zmietla zo stola klasickú (historickú) tézu o jeho výhradnej tónovosti a klasicko-romantických kvalitách. Profesionálne vzdelávaní hudobníci sa $\mathrm{v}$ rámci tradičnej vysokoškolskej estetiky nemajú možnost’ oboznámit’ s aktuálnym diskurzom filozofie umenia, takže si nevedia ani poradit so štandardnou akademickou diskusiou na tému: „každá hudba nie je umením“ (pretože tu nejde o definičný problém hudby samej, ale o konkrétnu ontologickú pozíciu, $\mathrm{z}$ ktorej sa $\mathrm{k}$ hudbe pristupuje, ide teda o problém hudobnej filozofie). Nielen študenti, ale ani mnohí akademici dosial' nechápu dôležitost', ba nevyhnutnost' kultivovania odlišných diskurzov vztahujúcich sa k hudbe v závislosti od toho, či ide o hudobné umelecké dielo, alebo o hudbu, ktorá sleduje odlišné sociálno-kultúrne ciele a realizuje sa špecifickými tvorivými procesmi, v ktorých netreba hladat artistické ambície (ani uplatňovat’ artistické estetické kritériá). Nastolovanie takýchto či podobných tém je kompetenciou hudobnej estetiky a kultivovanie takýchto diskusií je primárnou úlohou jej propedeutiky. Monografia Slávky Kopčákovej je $\mathrm{z}$ tohto pohladu vydareným pokusom o stratifikáciu vybraných typov a úrovní myslenia o hudbe, ktoré reprezentujú súčasnost' (samozrejme s jasne deklarovaným umenovedným dôrazom). Výsledky autorkinej práce na tomto poli sú na Slovensku jedinečné, aj ked' možno očakávat', že predložené stratifikácie hudobnoestetického myslenia (hudobnoestetických škôl) budú podliehat d’alšiemu vývoju už len preto, že viacero zmieňovaných estetikov stále pracuje a nad’alej rozvíja (t. j. i modifikuje) smerovanie svojho výskumu.

Najnovšia publikácia Slávky Kopčákovej má teda potenciál nezostat' len vedeckou monografiou, ale ponúka sa i ako špecifický učebný text. Poskytuje možnost' získavat’ kompetencie pre aktuálny diskurz o hudbe a zároveň informuje o alternatívach takéhoto diskurzu. Dosial' sa totiž u nás text v podobe sumáru aktuálnych podôb hudobnej estetiky neobjavil. Text Slávky Kopčákovej je do istej miery takýmto sumárom (k vybraným témam), ktorý sa navyše pokúša o široko rozkročenú komparáciu tým, že slovenské hudobnoestetické myslenie umiestňuje do medzinárodného kontextu myslenia o hudbe. Publikácia Aktuálne otázky hudobnej estetiky 20. a 21. storočia je teda nielen kvalitným príspevkom $\mathrm{k}$ aktualizácii slovenskej hudobnej estetiky, ale nepochybne sa stane i vítaným študijným doplnkom $\mathrm{k}$ dejinám a súčasnosti hudobnoestetického myslenia pre filozofické fakulty i umelecké vysoké školy a akadémie.

Renáta Beličová 